\title{
PEMBERDAYAAN UMKM UDANG KETAK PADA PENGOLAHAN UDANG KETAK DI KECAMATAN KUALA JAMBI TANJABTIM PROPINSI JAMBI
}

\author{
Metha Monica ${ }^{1}$, Hajar Setyaji², Suryanto ${ }^{2}$ \\ ${ }^{1}$ Dosen Fakultas Peternakan Universitas Jambi \\ ${ }^{2}$ Dosen Fakultas Pertanian Universitas Jambi \\ E-mail: methamonica@yahoo.com
}

\begin{abstract}
ABSTRAK
Daerah pantai yang sering disebut sebagai wilayah pesisir merupakan daerah yang sangat spesifik seperti Kecamatan Kuala Jambi, karena daerah ini merupakan daerah yang berada di perbatasan antara pengaruh daratan dan lautan. Mengingat posisi geografisnya, daerah pantai merupakan daerah penghubung antara daratan dan lautan sangat strategis sebagai usaha pengembangan sektor perikanan spesifik lokal (Juarini,2002). Salah satu usaha pengembangan sektor perikanan spesifik lokal khususnya di Propinsi Jambi adalah usaha agribisnis udang ketak. Kegiatan ini dilakukan dari Bulan Mei - November tahun 2017. Mitra yang dilibatkan adalah 2 (dua) Kelompok UMKM, UMKM Bangau yang berada di Kelurahan Majelis Hidayah di ketuai oleh Ridho Ardiansyah dan UMKM Elang yang berada di Kelurahan Kampung Laut diketuai oleh Muamar. Kedua UMKM berada di Kecamatan Kuala Jambi Kabupaten Tanjabtim. Pelaksanaan Kegiatan dilakukan dengan 5 (lima) tahapan yaitu persiapan, penyuluhan, kegiatan lapangan, pembinaan dan penyusunan laporan. Permasalahan Mitra adalah Sumberdaya Manusia, Modal, Bahan Baku dan Penguasaan teknologi tentang pengolahan udang ketak. Tujuan yang ingin dicapai dari kegiatan ini adalah : a. Memotivasi dan mengembangkan kemampuan teknis penerapan teknologi sederhana pengolahan udang ketak/ mantis shrimps pada usaha mikro, kecil dan menengah (UMKM) udang ketak yaitu Pengolahan udang ketak yang sudah diberi sambal tomat dan terasi serta dikemas plastik dan divakum; b. Mengembangkan usaha olahan udang ketak yang siap dijual; c. Menambah pendapatan usaha mikro, kecil dan menengah (UMKM) udang ketak di Kecamatan Kuala Jambi d. Adanya kerjasama antara Perguruan Tinggi dan UMKM. Sasaran yang ingin dicapai yaitu : Penerapan teknologi sederhana dengan cara pengolahan udang ketak diberi bumbu, sambal nenas dan terasi, dikemas vakum dan ada izin IRT serta siap dijual sehingga meningkatkan nilai jual udang ketak secara lokal (Jambi, Jakarta, Yogyakarta, Batam) . Hasil luaran yang dicapai adalah Penyerahan barang untuk pengolahan udang ketak berupa food processor, gas $3 \mathrm{~kg}$, vacuum sealer, freezer, dandang, kompor gas dan selang, nampan dan centong, pelatihan pengolahan udang ketak mulai dari buat sambal tomat dan terasi serta pengemasan udang ketak dengan plastik dan divakum, pengurusan izin P-IRT. Kesimpulan Penyerahan alat yang digunakan untuk pengolahan udang ketak berupa food processor, gas $3 \mathrm{~kg}$, vacuum sealer, freezer, dandang, kompor gas dan selang, nampan dan centong, Pelatihan pengolahan udang ketak mulai dari pembuatan sambal sampai pengemas udang ketak, Pengurusan Izin P-IRT sudah sampai BPOM Propinsi Jambi dengan Nama Hidayah (UMKM Bangau) dan Nama Mr. J. (UMKM Elang)
\end{abstract}

Kata kunci: Udang Ketak, UMKM, Kuala Jambi

\section{PENDAHULUAN}

Udang ketak ini merupakan salah satu produk perikanan unggulan di Propinsi Jambi terutama Kabupaten Tanjabtim dan Tanjabbar. Udang ketak diperoleh dari tangkapan di alam (laut). Udang ketak di jual dalam bentuk segar dan hidup. Apabila tidak hidup udang ketak tidak laku di jual dan tidak mempunyai daging. Udang ketak yang di jual mempunyai ukuran B (7,5 Inchi) sampai Jumbo/ SP (9,2 inchi). Sedangkan ukuran kecil /KK ( $<5$ inchi) tidak laku di jual, dimana udang ketak ukuran kecil di konsumsi sendiri oleh nelayan atau dibiarkan mati dan di buang.

Udang ketak di jual dalam bentuk segar dan hidup. Kalau tidak segar dan hidup tidak laku di jual karena tidak ada dagingnya dan hanya kulitnya saja. Udang ketak yang di jual dengan ukuran B (7,5 Inchi) sampai Jumbo/ SP (9,2 inchi) dengan harga kisaran Rp. 20.000 - Rp. 50.000 Udang ketak tidak pernah dijual dalam bentuk olahan.

Dengan uraian diatas perlu dilakukan pengabdian masyarakat terutama UMKM Udang Ketak di Kecamatan Kuala Jambi Kabupaten Tanjabtim untuk melakukan pengolahan udang ketak.

\section{METODE PELAKSANAAN}

\section{Tempat dan Waktu}

Kegiatan ini dilakukan pada 2 (dua) kelompok UMKM yaitu UMKM Bangau dan UMKM Elang yang ada di Kecamatan Kuala Jambi Tanjabtim Jambi. Sedangkan waktu pelaksanaan dari bulan Mei - November 2017. 


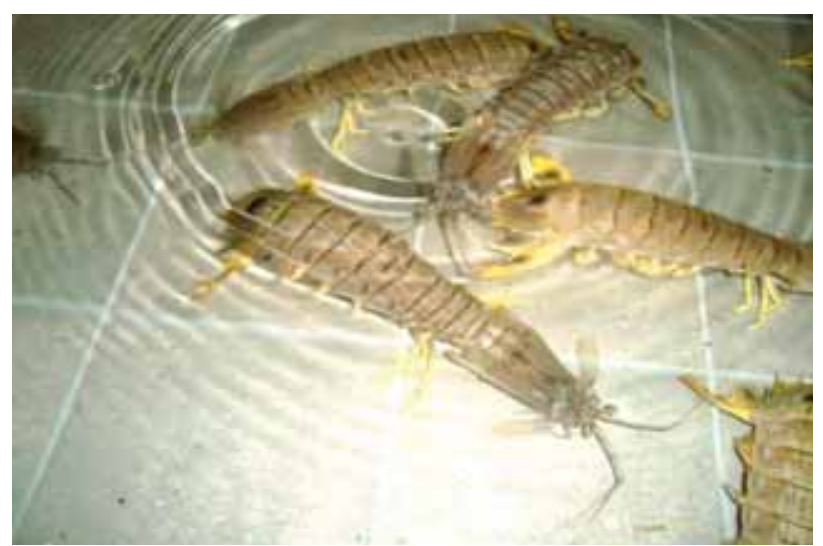

Gambar 1. Udang Ketak Yang Hidup

Prosedur kerja untuk mendukung realisasi metode yang ditawarkan.

Kegiatan ini akan dilakukan dengan penekanan pada metode partisipasi aktif kelompok sasaran. Kelompok sasaran yang terlibat dalam kegiatan ini adalah kelompok usaha mikro, kecil dan menengah (UMKM) udang ketak (Bangau dan Elang) dengan para nelayannya. Pendekatan pada metode ini diharapkan kelompok sasaran dapat menguasai proses teknologi sederhana pengolahan udang ketak yang disertai sambal terasi dan tomat, selain itu udang ketak dikemas plastik dan divakum.

Mekanisme kegiatan ini akan dilaksanakan melalui beberapa tahap yaitu: penetapan kelompok sasaran, penyuluhan, dan kegiatan lapangan, pembinaan dan monitoring serta evaluasi kemajuan program.

\section{HASIL DAN PEMBAHASAN}

Dalam konteks pembangunan agribisnis, setiap daerah perlu mengembangkan kegiatan agribisnis secara spesifik berdasarkan keunggulan masing-masing daerah (Krisnamurthi,1999). Dilain pihak, luas lautan Indonesia yang lebih besar dari daratannya merupakan sumber daya alam yang potensial untuk dikembangkan seperti usaha agribisnis.

Daerah pantai yang sering disebut sebagai wilayah pesisir merupakan daerah yang sangat spesifik seperti Kecamatan Kuala Jambi, karena daerah ini merupakan daerah yang berada di perbatasan antara pengaruh daratan dan lautan. Mengingat posisi geografisnya, daerah pantai merupakan daerah penghubung antara daratan dan lautan sangat strategis sebagai usaha pengembangan sektor perikanan spesifik lokal (Juarini,2002). Kecamatan Kuala Jambi terkenal sektor perikanan seperti udang ketak terutama pengolahannya karena udang ketak pada UMKM Bangau dan Elang yang ada di Kecamatan Kuala Jambi Kabupaten Tanjabtim Propinsi Jambi belum pernah diolah hanya di jual segar. .
Usaha mikro, kecil dan Menengah (UMKM) yang umumnya melibatkan banyak orang baik sebagai pemilik usaha maupun tenaga kerja, tampaknya dipercaya banyak pihak dapat menjadi solusi untuk menggerakkan aktivitas ekonomi riil di Indonesia umumnya dan Propinsi Jambi khususnya. Kendala yang dihadapi oleh usaha mikro, kecil dan menengah (UMKM) dalam mengemban usahanya pada umumnya masih merupakan kendala klasik seperti keterbatasan akses terhadap sumber pendanaan dan pemasaran. Namun demikian, dibalik kesulitan dana bagi pengembangan usaha mikro, kecil dan menengah (UMKM) terutama UMKM pemula terbanyak diantara mereka yang produknya mempunyai keunggulan komparatif .

Pengabdian ini dilakukan beberapa tahapan yaitu :

a. Persiapan

Kegiatan persiapan ini dilakukan supaya kegiatan selanjutnya berjalan dengan lancar seperti mempersiapkan alat untuk proses pengolahan udang ketak seperti freezer, vacuum sealer, food processor, kompor gas, selang dan gas elpiji $3 \mathrm{~kg}$, dandang, plastik vakum. Alat-alat tersebut diberikan pada UMKM Bangau dan UMKM Elang dengan Dana IbPUD tahun 2017. Alat-alat tersebut digunakan untuk kelancaran kegiatan pengolahan udang ketak ke depannya.

b. Penyuluhan

Kegiatan penyuluhan akan dilaksanakan di Kecamatan Kuala Jambi Kabupaten Tanjabtim untuk menambah pengetahuan dan meningkatkan ketrampilan UMKM udang ketak (Bangau dan Elang), memberikan motivasi untuk pengolahan dengan produk olahan dengan bumbu sambal terasi dan sambal tomat dilakukan dengan materi pokok yaitu:

- Syarat-Syarat Pengolahan yang baik

- Memilih bahan baku (udang ketak dan bumbu) yang berkualitas bagus

- Memilih bahan pengemas yang baik

- Sanitasi dan higienis produk (udang ketak) yang dihasilkan.

- Dianalisa gizi

- Izin IRT

c. Kegiatan Lapangan

Kegiatan ini akan dilaksanakan di lokasi UMKM udang ketak (Bangau dan Elang) di Kecamatan Kuala Jambi Kabupaten Tanjabtim

UMKM Bangau dan Elang diberi pelatihan cara pembuatan sambal terasi dan sambal tomat, pengolahan udang ketak dan cara pengemasan yang baik. Selain itu juga setelah pelatihan pengolahan udang ketak yang sudah dikemas akan diurus P-IRT supaya hasil olahan udang ketaknya dapat dipasarkan secara luas di luar Kecamatan Kuala Jambi.

Produk makanan terutama pengolahan udang ketak yang di kemas dengan diberi sambal tomat/ terasi supaya bisa 

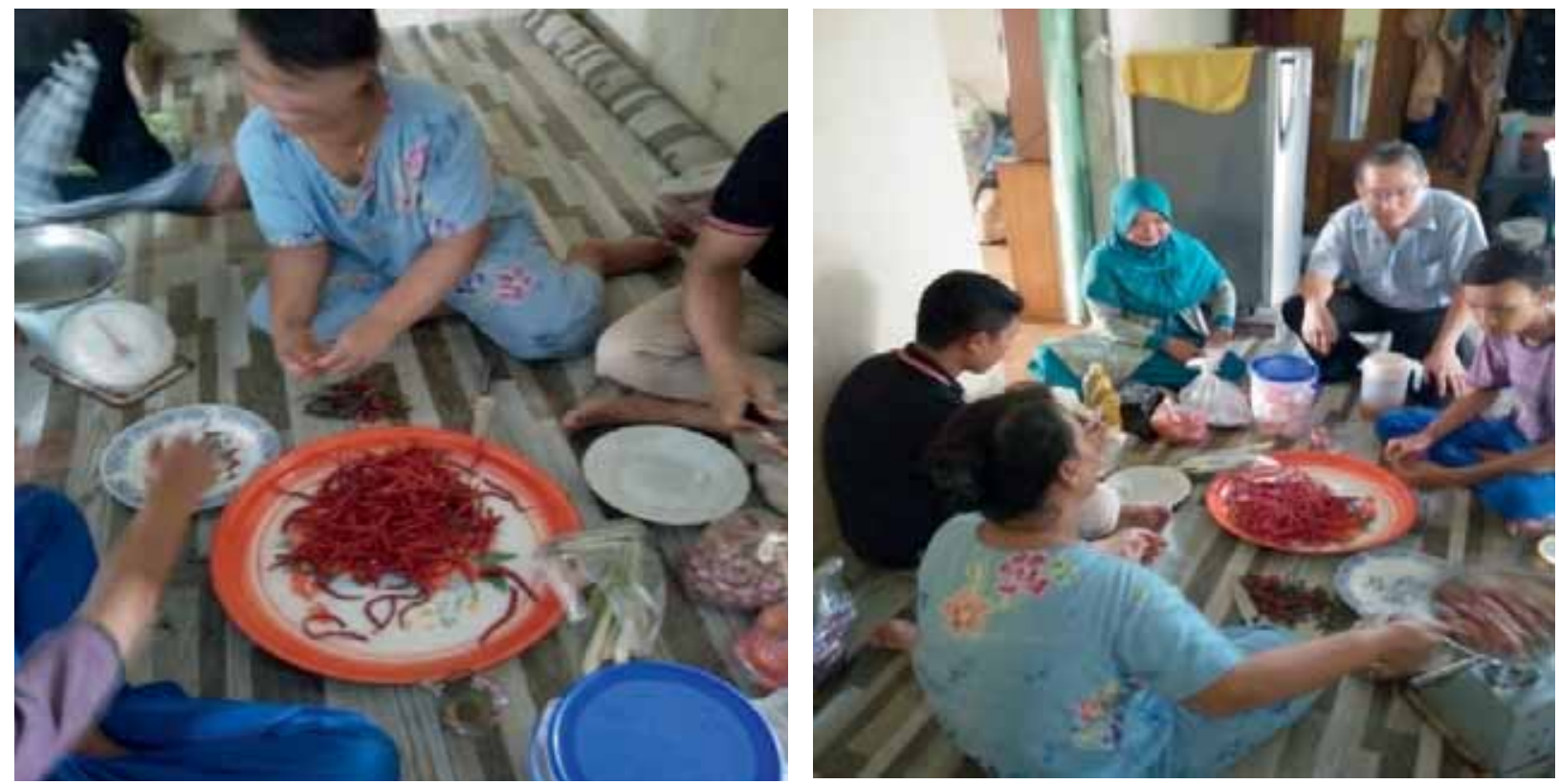

Gambar 2. Pelatihan Pembuatan Sambal
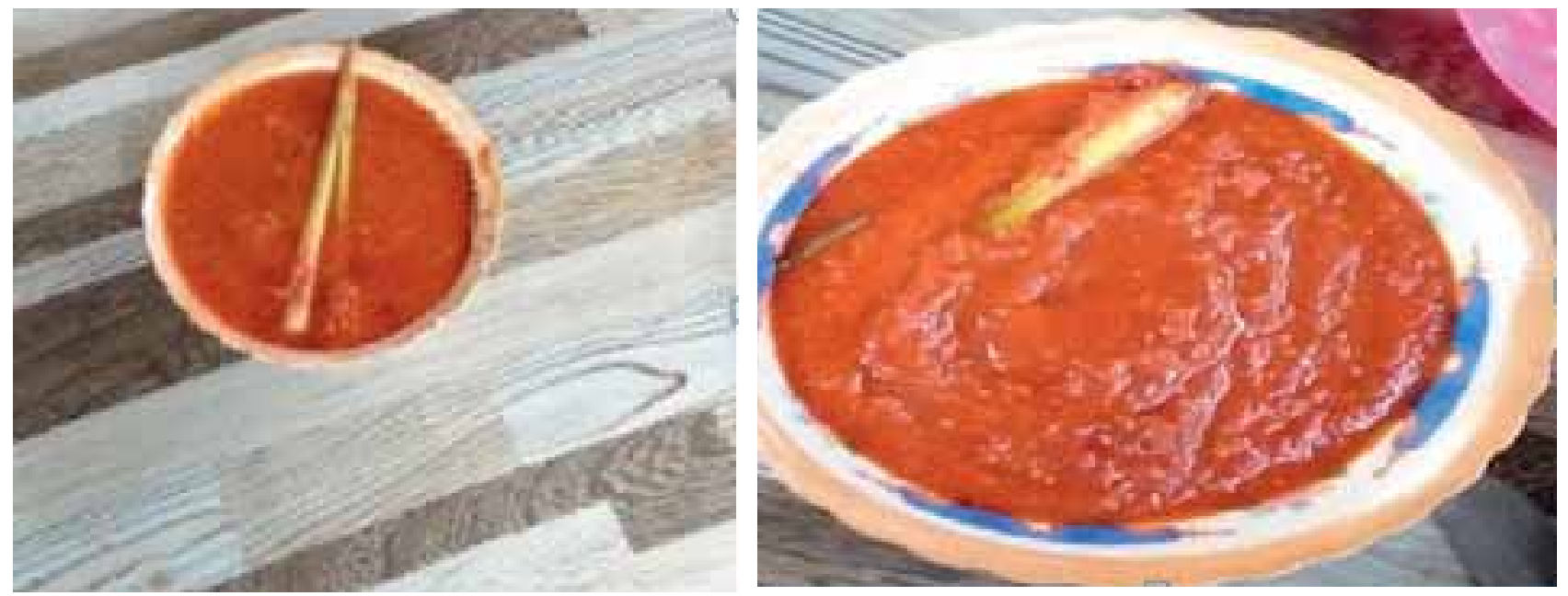

Gambar 3. Sambal Terasi dan Tomat

dipasarkan lebih luas harus mengurus izin P-IRT. Dengan adanya izin P-IRT konsumen aman untuk mengonsumsinya karena sudah diperiksa penggunaan bahan yang di gunakan oleh instansi bersangkutan (DEPERINDAG, DEPKES dan BPOM) untuk mengolah udang ketak. walaupun udang ketak yang dibuat bebas dari bahan pengawet apalagi yang berbahaya. Kalau tidak ada P-IRT konsumen masih ragu-ragu mengonsumsinya kecuali konsumen kenal langsung dengan UMKM/penjualnya.

Pengurusan izin P-IRT sudah sampai ke BPOM Propinsi Jambi Dengan pengurusan izin ke UMKM harus mempunyai merk masing-masing. Merk yang di pakai oleh UMKM Bangau adalah Hidayah, Sedangkan UMKM Elang adalah Mr. J.

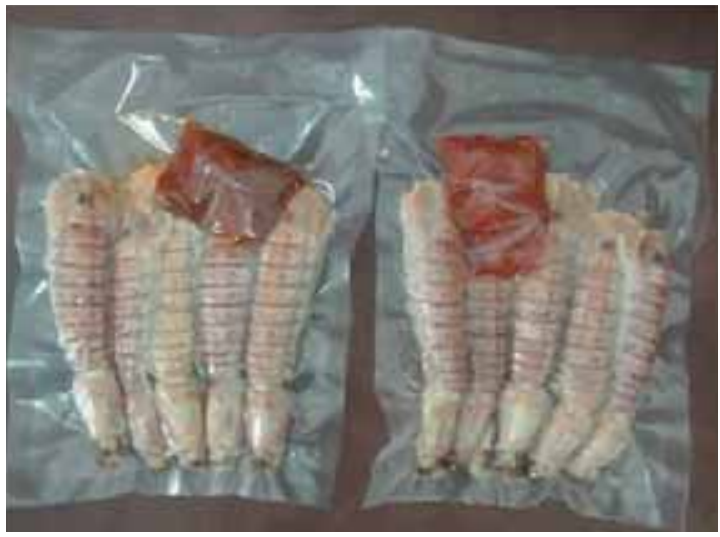

Gambar 4. Udang Ketak Yang Sudah Dikemas 


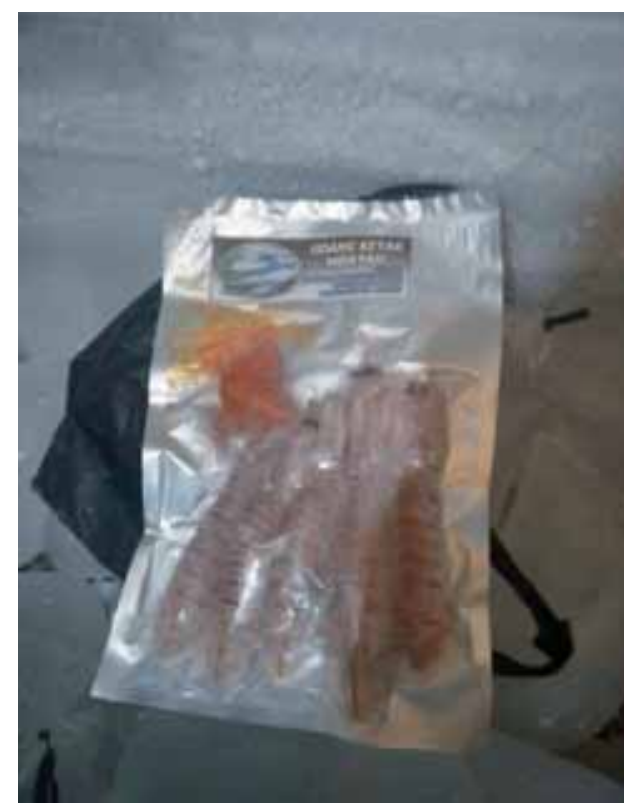

Gambar 5. Produk Udang Ketak UMKM Bangau dengan Nama "Hidayah"

d. Pembinaan

Pelaksanaan kegiatan ini diperlukan pendampingan, untuk pembinaan lapangan dan dapat secara langsung membantu memonitor perkembangan pengolahan udang ketak adalah Ketua dan Anggota tim bersama-sama ke Lokasi selama program kegiatan pengabdian IbPUD berjalan Kegiatan ini akan dilaksanakan di lokasi UMKM udang ketak (Bangau dan Elang) di Kecamatan Kuala Jambi Kabupaten Tanjabtim dengan kegiatan yang berkesinambungan, sampai tujuan tercapai. Supaya kegiatan ini berlangsung maka di lakukan pengurusan izin P-IRT. Pengurusan izin sudah sampai pada BPOM Propnsi Jambi. UMKM juga ingatkan bahwa pengolahan udang ketak harus bersih, tanpa menggunakan pengawet dan pembuatan sambalnya tidak menggunakan MSG, bahan-bahan yang digunakan adalah bahan alami seperti bawang putih, bawang merah, cabe, tomat, terasi, sereh, merica.

e. Penyusunan laporan.

Setelah kegiatan berjalan seperti perencanaan maka dibuat laporan

\section{KESIMPULAN}

Kegiatan ini dapat disimpulkan :

Kesimpulan dari kegiatan ini adalah

a Penyerahan alat yang digunakan untuk pengolahan udang ketak berupa food processor, gas $3 \mathrm{~kg}$, vacuum sealer, freezer, dandang, kompor gas dan selang, nampan dan centong.

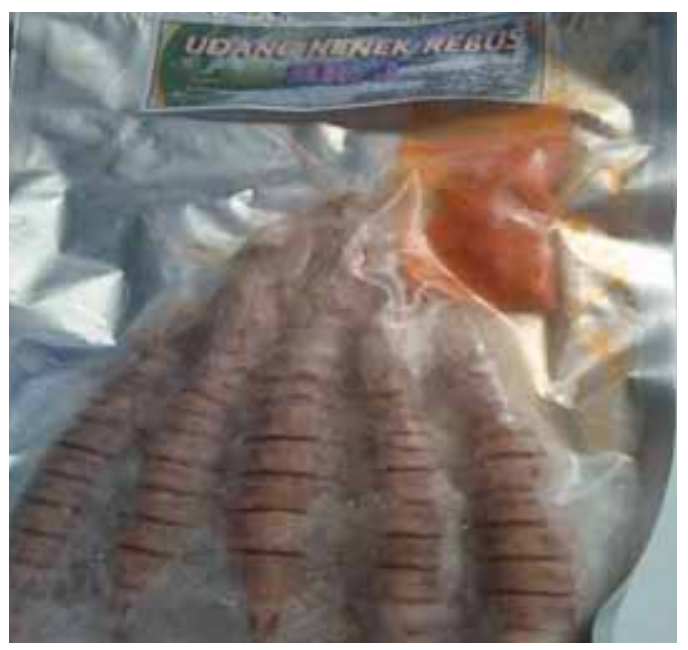

Gambar 6. Produk Udang Ketak UMKM Elang dengan Nama "Mr. J"

b Pelatihan pengolahan udang ketak mulai dari pembuatan sambal sampai pengemas udang ketak secara vacuum dengan menggunakan bahan baku yang alami.

c Pengurusan Izin P-IRT masih dalam proses (BOPM Propinsi Jambi)

\section{UCAPAN TERIMA KASIH}

Kegiatan Pengabdian ini dibiayai oleh Kegiatan IbPUD Tahun 2017 oleh Kemenristek Dikti Jakarta.

\section{DAFTAR PUSTAKA}

Lai, C.H., Tsui, J.C.Y. \& Leung, K.M.Y. (2003). Distribution and demography of Stomatopoda in the subtidal marine environment of HongKong. In: Turning the Tides - A Festschrift in Honour of Professor Brian Morton, (ed. P.K.S. Shin), The Marine Biological Association of Hong Kong,Hong Kong. pp. 159-183

Moriarty D. J. W. 1999. Microbial biosystem; New Frontiers' in: Bell C. R. Rrylinsky M., Johnson GP (Editor). Proceeding of the 8th International Symposium on Microbial Ecology. Canada.

Pangabean, L.M.G. 1998. Mikroalgae : Alternatif Pangan dan Bahan Industri di Masa Mendatang. J. Oseana Volume XXIII Nomor 1, 1998 : 19 - 26.

Seamolec. 2009. Teknologi Pengelolaan Kualitas Air: Kualitas Biologis dan Manipulasi Mikroba: Probiotik. ITB Bandung

Sheehan, J., T. Dunahay, J. Benemann, P. Roessler, (1998). A look Back at The U.S. Department of Energy's Aquatic Species. 